ENTREPRENEURSHIP AND SUSTAINABILITY ISSUES

ISSN 2345-0282 (online) http://jssidoi.org/jesi/

2020 Volume 7 Number 4 (June)

http://doi.org/10.9770/jesi.2020.7.4(56)

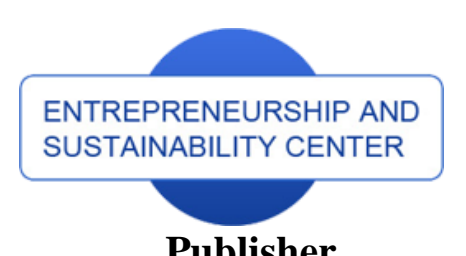

Publisher

http://jssidoi.org/esc/home

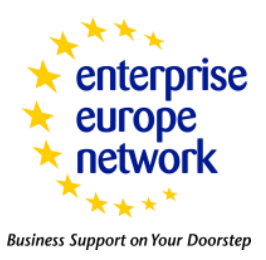

CASPA

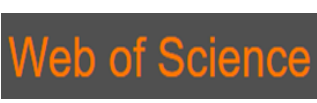

I Clarivate

\title{
WOMEN ENTREPRENEURSHIP IN COASTAL KERALA: ROLE OF SELF HELP GROUPS IN DEVELOPING A SUSTAINABLE COMMUNITY*
}

\author{
Minimol M C \\ 'Rajagiri College of Social Sciences, Rajagiri Valley P O, Kakkanad, Kochi, Kerala, India \\ E-mail:minimol@rajagiri.edu
}

Received 15 March 2020; accepted 26 May 2020; published 30 June 2020

\begin{abstract}
The study was intended to examine the role of SHGs in promoting sustainable entrepreneurial competencies among members and to check whether the entrepreneurial competencies among women micro entrepreneurs can be discriminated based on their membership status in SHGs. The study investigated the opinion of SHG members and non-members in order to understand the cognitive part of entrepreneurial competencies among women micro entrepreneurs in coastal Kerala. The field data collected were supplemented with focus group interactions. Discriminant Analysis was performed to identify whether the status of membership in SHGs is a good predictor of their entrepreneurial competency. The results reveal that the prediction model is statistically significant, and that the status of membership in SHGs is capable of predicting the outcome variable.
\end{abstract}

Keywords: women entrepreneurship; entrepreneurial competencies; self help groups; micro entrepreneurs; neighbourhood groups; sustainable community

Reference to this paper should be made as follows: M C, Minimol. 2020. Women Entrepreneurship in Coastal Kerala: Role of Self Help Groups in Developing a Sustainable Community. Entrepreneurship and Sustainability Issues, 7(4), 3426-3437. http://doi.org/10.9770/jesi.2020.7.4(56)

JEL Classifications: M54, N35, O35

\section{Introduction}

The sustainable development of rural economy is very important as it increases rural employment opportunities, reduces regional income imbalances, prevents rural-to-urban migration, and reduces poverty at its own root. But at policy level, the overarching importance of rural economy has not been adequately recognized (Anriquez and Stamoulis, 2007). For ages, the formal financial system has consistently failed to cater to the credit needs of the

\footnotetext{
* This research was supported by the Indian Council of Social Science Research (ICSSR), New Delhi, through its sponsored research programme.
} 


\section{ENTREPRENEURSHIP AND SUSTAINABILITY ISSUES}

ISSN 2345-0282 (online) http://jssidoi.org/jesi/

2020 Volume 7 Number 4 (June)

http://doi.org/10.9770/jesi.2020.7.4(56)

rural women. Due to lack of sufficient credit worthiness and collaterals, the rural women have been branded as sub-prime, and have been denied access to formal financial system. Within the wake of such deprivation, selfinitiated action of rural women to join themselves together to meet their credit needs by themselves should be considered to be a monumental effort. The entrepreneurial activities that sprout out from such informal groups can play a critical role in social revolution. In fact, the SHGs can act as a catalyst for the development of entrepreneurial competencies among members, percolating the benefits to the society in general. According to Sixth Economic Census published by the Indian Ministry of Statistics and Programme Implementation, women represent roughly 14\% of the total entrepreneurship in India (only 8.05 million out of the total 58.5 million entrepreneurs in India). Among this, 2.76 million women (13.3\% of women entrepreneurs) work in agricultural sector whereas 5.29 million women representing more than $65 \%$ work in non-agricultural sector. The average employment in women-owned enterprises is reported to be very meager 1.67 (Business Standard, 2018).

It is true that SHGs have been seen mainly as entities for savings and borrowings. This was the thinking of an earlier generation of SHGs, but today, in some parts of the country, SHGs are taking on new roles and responsibilities that lie at the very core of livelihood security for the poor and also developing entrepreneurship. Globalization has imposed severe constraints to sustainable livelihoods for poor women. This needs solutions that go beyond micro-credit. The SHGs play a major role in achieving a sustaining livelihood by facilitating the rural women to enter into entrepreneurial activities. Globally, it is slowly proving one of the most effective strategies to neutralize poverty. There are many instances that rural women form SHG groups but they are dysfunctional quite after their formation. It is due to lack of entrepreneurial skills among rural SHG women. Entrepreneurship amongst women has been a recent concern. However, it is observed that the development of women entrepreneurship is very low in India, especially in the rural areas.

SHGs are considered to be a powerful tool for alleviating poverty through empowerment of rural women. The poor women in coastal Kerala have well understood the possibilities of this and are choosing not to remain poor and curse their fate any more. The SHGs also contribute significantly to the empowerment and entrepreneurial competency development of coastal people. There is a general tendency to consider SHGs as a panacea for all the ills of the rural community. Review of the existing available literature makes it clear that research studies focusing on the role of Self Help Groups in facilitating development of entrepreneurial competencies, among coastal women, especially in Kerala are rare in nature. It is specifically against this setting that the present study was undertaken to critically evaluate the role-played by the SHGs in imparting entrepreneurial competencies, among micro entrepreneurs in coastal Kerala.

Specifically, the research questions in this study are:

- Whether or not entrepreneurial competencies can discriminate between members and non-members of SHGs.

- What is the level of entrepreneurial competencies achieved through participation in various entrepreneurial activities by the members of SHGs.

To find solutions to the research questions, the following hypothesis was tested in this study:

- SHG members and non-members cannot be discriminated based on their entrepreneurial competencies.

\section{Literature Review}

Siwan Mitchelmore and Jennifer Rowley (2010) had undertaken a literature review of research on entrepreneurial competence in order to provide an integrated account of contributions relating to entrepreneurial competencies by different authors working in different countries and different industry sectors and at different points in time; and, develop an agenda for future research, and practice in relation to entrepreneurial competencies. After a lengthy examination various literature in the field of entrepreneurial competencies, they suggest that although the concept 


\section{ENTREPRENEURSHIP AND SUSTAINABILITY ISSUES}

ISSN 2345-0282 (online) http://jssidoi.org/jesi/

2020 Volume 7 Number 4 (June)

http://doi.org/10.9770/jesi.2020.7.4(56)

of entrepreneurial competencies has been used widely by government agencies and others in their drive for economic development and business successes, the core concept of entrepreneurial competencies, its measurement and its relationship to entrepreneurial performance and business success is in need of further rigorous research and development in practice. Many researchers have taken efforts to study the components of entrepreneurial competency and its impact on entrepreneurial performance. Competency is concerned with the long term performance of a firm, an industry or a country related to its competitors says Ramasamy (1995). It is also a multi dimensional concept, including not only performance, but also potential and the process of generating performance (Buckley et al, 1998). Further the qualitative analysis done by Lau, Chan and Man (2000) about "Entrepreneurial competency of SME owners/managers in the Hong Kong Service Sector", revealed the relationship between behavioural bases and competency. The competency approach is a way of studying individual characteristics leading to the accomplishment of job role. It has been widely applied to the study of managerial performance since the work of Boyatzis (1982) and increasingly in the field of entrepreneurial performance. By using various qualitative techniques, many studies have been conducted to identify different entrepreneurial competency in different contexts (Adam \& Chell, 1993; Bird, 1995; Thandabhani, 2020). For the purpose of the present study, entrepreneurial competencies are defined as individual characteristics that include both attitude and behaviours, which enable entrepreneurs to achieve and maintain business success. In this study entrepreneurial competency comprised of entrepreneur's motives, traits, self-image, attitude, behaviours, skills and knowledge (Boyatzis,1982; Brophy \& Kiely, 2002), measured with the help of 47 variables, which were grouped into four different factors.

By drawing upon the concept of competitiveness and the competency approach, Man et al. (2002) proposed a conceptual model linking the characteristics of small and medium sized enterprises' (SMEs) owner-managers and their firms' performance. In Man et al. (2002)'s model, entrepreneurial competencies play a key role in determining firm performance. Although competitive scope and organizational capabilities still are two determinants of firm performance, they are influenced by entrepreneurial competencies. Empirically, significant relationships between entrepreneurial competencies and firm performance are reported. Chandler and Jansen (1992) find that the founder's self-assessed entrepreneurial competencies are positively related to firm growth. Chandler and Hanks (1994) again find that entrepreneurial competencies are directly correlated with venture growth. Baum et al. (2001) find that CEOs' specific competencies, which consist of industry skill and technical skill, have significant direct effects on venture growth, while CEOs' general competencies, which are composed of organizational skill and opportunity recognition skill, have significant indirect effects on venture growth. In a more recent paper, Sony and Iman (2005) confirm that entrepreneurial competencies which comprise management skill, industry skill, opportunity skill, and technical skill are positively related to venture growth.

Literature review suggests that definitions of competency may be drawn from the domain of knowledge, skill, attitude and performance indicators. The term competency has a number of definitions which depend on the specific task to be performed by individuals under different conditions. These definitions differ on different counts. Competency was first popularized by Boyatzis (1982), who performed a comprehensive study of over 2000 managers and he identified and assessed over a hundred potential competencies. He defined competency as, "A capacity that exists in a person that leads to behavior that meets the job demands within the parameters of organizational environment, and that, in turn brings about desired results". The competency is considered to be an underlying characteristic that an individual brings to a job situation, which can result in effective and/or superior performance in such job. McClelland (1973) claimed that competencies could be used for predicting job performances and further he held that competencies were not biased by race, gender or socio-economic factors. His study helped to identify performance aspects which are not attributable to a worker's intelligence or degree of knowledge and skill.

For Spencer and Spencer (1993) competency is an underlying characteristic of an individual that is causally related to criterion referenced effective and/or superior performance in a job or situation. Similarly, competency is 


\section{ENTREPRENEURSHIP AND SUSTAINABILITY ISSUES}

ISSN 2345-0282 (online) http://jssidoi.org/jesi/

2020 Volume 7 Number 4 (June)

http://doi.org/10.9770/jesi.2020.7.4(56)

a set of skills, related knowledge and attributes that allow an individual to successfully perform a task or an activity within a specific function or job (UNIDO, 2002). Although these definitions vary in different forms, some components are found commonly in all the definitions. For Example, Competency is composed of knowledge, skills, abilities and other characteristics, which underlie effective or successful job performance. These competency attributes are observable and measurable; and these attributes distinguish between superior and other performers.

In fact, competency is a wider concept which includes the knowledge, attitudes, behaviors and skills which help a person capable of transforming his/her ideas in to realities with an excellence in performance in a given context. It does not refer to those behaviours, which do not demonstrate excellent performance. Therefore, they do not include knowledge, but do include "applied" knowledge or the behavioral application of knowledge that produces success. In addition, competencies do include skill, but only the manifestation of skills that produce success. Finally, competencies are not work motives, but do include observable behaviors related to motives.

Based on the work of Boyatzis (1982), entrepreneurial competencies are underlying characteristics possessed by a person which result in new venture creation, survival, and/or growth (Bird, 1995). These characteristics include generic and specific knowledge, motives, traits, self images, social roles, and skills that may or may not be known to the person (Boyatzis, 1982). That is, these characteristics may be even unconscious attributes of an individual. Some of these competencies are innate while others are acquired in the process of learning and training and development.

Muzychenko and Saee (2004) differentiate between innate and acquired aspects of competencies of an individual. The former involve traits, attitudes, self image and social roles and are sometimes referred to as "internalised elements" (Bartlett \& Ghoshal, 1998) and the latter involve components acquired at work or through theoretical or practical learning (i.e., skills, knowledge, and experience). The 3429 aspects of competencies are difficult to change, whereas the 3429 elements can be acquired through proper training and education programs and need to be practiced (Garavan \& McGuire, 2001; Man \& Lau, 2005). In the context of a small business enterprise, these competencies are normally studied as characteristics of the entrepreneur, who owns and actively manages the business (Gibb, 2005; McGregor \& Tweed, 2002). Stuart and Lindsay (1997) also defined competencies as a person's skills, knowledge, and personal characteristics. Entrepreneurial competencies have also been understood in terms of traits, skills and knowledge (Lau et al., 2000). Sreemoyee et al. (2015) pointed out that during the last 30 years, the focus of rural development practitioners was on the role of SHGs in promoting women entrepreneurs in India. They concluded that irrespective of large numbr of social and economic constraints, there are a number of women entrepreneurs grommed by self help groups. Women are really significant part of the human resource of every nation and hence every state should attempt to develop them as facilitators of economic growth and advancement. Reinforcement of women entrepreneurship is one among the approaches for that (Kumar, 2018; Schouten, 2019).

Sharmina et.al (2008) mentioned the financial management skills and the group identity of the women borrowers have significant relationship with the development of rural women entrepreneurship in Bangladesh. Sujata et.al (2010) mentioned lack of supportive network, financial and marketing problems was the major problem areas for rural women entrepreneurs and major de motivator for other women to initiate entrepreneurial activity. Ashok (2013) pointed out that to alleviate the poverty and to empower the women, the micro-finance has emerged as a powerful instrument in the new economy. With availability of micro-finance, self-help groups (SHGs) and credit management groups have also started in India. And thus the movement of SHG has spread out in India. Though women entrepreneurship is a recent phenomenon in India which came into prominence in late 1970's now one can see that more and more women are venturing as entrepreneurs in all kinds of business and economic activities and service sector. Though at the initial stage women entrepreneurship developed only at urban areas, lately it has extended its wings to rural areas. Entrepreneurship is a process where one person getting himself self employed 


\section{ENTREPRENEURSHIP AND SUSTAINABILITY ISSUES}

ISSN 2345-0282 (online) http://jssidoi.org/jesi/

2020 Volume 7 Number 4 (June)

http://doi.org/10.9770/jesi.2020.7.4(56)

provides job to others also. The person is called "entrepreneur". Women entrepreneurship is the process where women take lead and organize a business or industry and provide employment opportunities to others. Entrepreneurship development means all those activities that aim at stimulating the individuals for becoming entrepreneurs. Yadav \& Unni (2016) examined the number of papers published on women entrepreneurship in 12 established entrepreneurship journals from 1900 to 2016. They assessed the growth of the field by specifically reviewing literature reviews published from 1980s till 2016 and put forward future research directions and suggested that the lens of feminist theories can be applied in conjunction with the existing entrepreneurship theories to advance the field. Thyagaraj (2017) pointed out that women entrepreneurship must be moulded properly with entrepreneurial traits and skills to meet the changes in trends, challenges global markets and also be competent enough to sustain and strive for excellence in the entrepreneurial arena. Highly educated, technically sound and professionally qualied women should be encouraged for managing their own business, rather than dependent on wage employment outlets. The unexplored talents of young women can be identied, trained and used for various types of industries to increase the productivity in the industrial sector. Ngoasong and Kimbu (2019) examine how embeddedness within a resource-scarce context influences high-growth women's entrepreneurship. Using 16 qualitative cases developed in Cameroon, a factor-driven economy, they identify how entrepreneurial path creation by women entrepreneurs enables their ability to grow. Their study suggests that while highly embedded women entrepreneurs can easily access resources and win legitimacy resulting in high-growth businesses, they can also be locked into existing systems that constrain their growth development paths.

A study undertaken by Hemalatha (2012), with the objectives to analyse the Women Entrepreneurship Development in Hatkanangale Taluka, to know the role played by SHGs in Women Entrepreneurship Development, to analyse income, expenditure and profit of women entrepreneurs, to find the drawbacks and to provide appropriate suggestions to improve women entrepreneurship, concluded that formation of groups and the resultant establishment of micro enterprises give the indication that SHGs could bring in a positive impact in the society. Minimol(2017) analysed the levels of entrepreneurial competency and social entrepreneurship among micro entrepreneurs in Kerala. The study tried to identify the relationship between entrepreneurial competency and social entrepreneurship and develop a theoretical model that explains the linkage between these variables. The study concluded that entrepreneurial competency contributes to social entrepreneurship among women micro entrepreneurs.

\section{Materials and Methods}

The sample respondents were selected by using multi-stage, simple random sampling technique. Population for the study was taken as the entire women micro entrepreneurs in coastal Kerala, who are divided into members and non-members of Self Help Groups/NHGs. In the first stage, three districts (Alappuzha, Kollam, Thiruvananthapuram) were selected from the entire state of Kerala by considering the number of SHGs functioning there. In the second phase, 10 SHGs (Neighbourhood Groups consisting of 10-20 women members from the same neighbourhood) were chosen from each district, by giving due consideration to the factors such as year of formation, number of members, the amount of savings and loans, number of Income-Generating Activities (IGAs) undertaken and thrift per member. 300 women members of Self Help Groups were selected, using the list of members from each group to constitute the sample in the third phase. Attempt was made to elicit response from all the members of the selected 30 SHGs. However, in very rare cases, where members were not accessible after repeated attempts, one or two members were dropped from the list of respondents. Accordingly, the number of respondent members was 98 from Trivandrum, 103 from Kollam and 102 from Alappuzha, totaling 300. Three responses were excluded from analysis for being incomplete. Thus, the sample size came to 300, made up of 97 , 102 and 101 respondents from the three districts. In order to investigate whether or not entrepreneurial competencies can discriminate between members and non-members of SHGs, data were also elicited from 100 


\section{ENTREPRENEURSHIP AND SUSTAINABILITY ISSUES}

ISSN 2345-0282 (online) http://jssidoi.org/jesi/

2020 Volume 7 Number 4 (June)

http://doi.org/10.9770/jesi.2020.7.4(56)

non-members of SHGs, from the three districts. Thus, the final sample for the study consists of 300 members of SHGs and 100 non-members of SHGs, totaling a sample size of 400 . More than 60 percent of the members belong to 45 years and above age category, while among non-members, 72 percent belongs to this group. 80 percent of the members are having only primary education, whereas 50 percent of the non-members are either graduates or post graduates. 62 percent of the member respondents belong to the lower income strata, while it is 70 percent among non-member respondents. Discrimiinant analysis was used to find out whether or not entrepreneurial competencies can discriminate between members and non-members of SHG.

\section{Results and Discussion}

Level of entrepreneurial competency. Entrepreneurial competency of the respondents was measured using 49 statements on a five-point scale ranging from Very High to Very Low. Responses were assigned weights ranging from 5 to 1 for each response. Weighted scores of each respondent was summed up and averaged. The average weighted score was then classified into Low, Medium and High.

The level of entrepreneurial competency of member-respondents and non-member respondents are tabulated (Table 1) and presented below. Among the respondents who were members of SHGs, 219 were identified as having Medium Level of Entrepreneurial Competency, while 45 had High Level of Competency. Among the nonmember category, 87 had Medium Level of Competency while 13 had Low level.

Table 1. Entrepreneurial Competency: Categorization of Members and Non-Members

\begin{tabular}{|l|l|l|l|l|}
\hline \multirow{2}{*}{ Category } & Level of Entrepreneurial Competency & \multirow{2}{*}{ Total } \\
\cline { 2 - 4 } & Low & Medium & High & \\
\hline Member & 36 & 219 & 45 & 300 \\
\hline Non-Member & 13 & 87 & 0 & 100 \\
\hline TOTAL & 49 & 306 & 45 & 400 \\
\hline
\end{tabular}

Statistics reveal that member category of respondents had a Mean Score of 4.023 with Standard Deviation of 1.1037, while the non-member category had a Mean Score of 3.678 with Standard Deviation of 0.2880. See Table 2 for details.

Table 2. Entrepreneurial Competency of Members and Non-Members

\begin{tabular}{|l|l|l|l|}
\hline \multirow{2}{*}{ Category } & \multicolumn{3}{|c|}{ Statistical Measures } \\
\cline { 2 - 4 } & No. of Respondents & Mean & Std Deviation \\
\hline Member & 300 & 4.023 & 1.1037 \\
\hline Non-Member & 100 & 3.678 & 0.2880 \\
\hline
\end{tabular}

Difference in Entrepreneurial Competency between Members and Non-Members. T Test was employed to find the difference in Entrepreneurial Competency levels between members and non-members. Table 3 gives the details.

The Levene's Test for Equality of Variances shows F Value of 46.168, and a Significance Value of 0.00, when equal variances are assumed to exist. Thus, the two categories of respondents differed significantly in Variance of response. T Test [Equality of Variance Not Assumed] shows a T Value of 4.937 with a Significance level of 0.00. The $95 \%$ Confidence Interval of Difference is 0.2078 to 0.4827 . Thus, there exists significant difference [at $95 \%$ Confidence level] between the levels of entrepreneurial competency of members and non-members. 
Table 3. T Test: Difference in Entrepreneurial Competency (Members and Non-Members)

\begin{tabular}{|c|c|c|c|c|c|c|}
\hline \multirow{7}{*}{$\begin{array}{l}\text { Entrepreneurial } \\
\text { Competency }\end{array}$} & \multicolumn{6}{|c|}{ Levene's Test for Equality of Variances } \\
\hline & \multicolumn{4}{|c|}{ Equal Variance is: } & $\mathrm{F}$ & Sig. \\
\hline & \multicolumn{4}{|c|}{ (a) Assumed } & 46.168 & 0.00 \\
\hline & \multicolumn{4}{|c|}{ (b) Not Assumed } & & \\
\hline & \multicolumn{6}{|c|}{ T-Test for Equality of Means } \\
\hline & $\mathrm{T}$ & DF & Sig. & Mean Difference & \multicolumn{2}{|c|}{$\begin{array}{l}\text { 95\% Confidence Interval of } \\
\text { Difference }\end{array}$} \\
\hline & 4.937 & 385.1 & 0.00 & 0.345 & 0.2078 & 0.4827 \\
\hline
\end{tabular}

Entrepreneurial Competency: Members Vs. Non-Members. Discriminant Analysis was also performed to identify whether the levels of entrepreneurial competency exhibited by the respondents was a good predictor of their status of membership in SHGs. Simply, the objective was to see if their entrepreneurial competency levels would help to discriminate the respondents between being a member of SHG or non-member of SHG. Conversely, it examines whether there exist significant difference in the entrepreneurial competency levels of members of SHGs and non-members of SHGs.

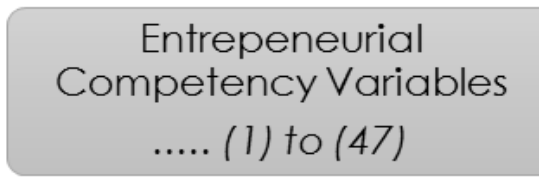

Independent Variables

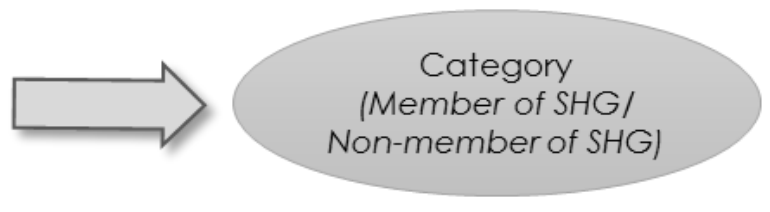

Dependent Variable

Figure 1. Discriminant Analysis Model

Source: Prepared by the Author

Table 4 shows the Box's M to be a very large 10300.374. The F Value is 7.458 , with a Significance value of 0.000. Since the significance value is less than 0.001, it is found that the group covariance is unequal. Thus, the null hypothesis of equal population covariance matrices stands rejected.

Table 4. Box Test of Equality of Covariance Matrix

\begin{tabular}{|l|l|l|}
\hline \multicolumn{2}{|l|}{ Box's M } & 10300.374 \\
\hline \multirow{4}{*}{ F } & Approx. & 7.458 \\
\cline { 2 - 3 } & df1 & 1128 \\
\cline { 2 - 3 } & df2 & 110557.456 \\
\cline { 2 - 3 } & Sig. & 0.000 \\
\hline Tests null hypothesis of equal population covariance matrices \\
\hline
\end{tabular}

Table 5 shows the Log Determinant values of the group covariance matrices. All the three Log Determinants are quite very similar to each other. 
ENTREPRENEURSHIP AND SUSTAINABILITY ISSUES

ISSN 2345-0282 (online) http://jssidoi.org/jesi/

2020 Volume 7 Number 4 (June)

http://doi.org/10.9770/jesi.2020.7.4(56)

Table 5. Log Determinants

\begin{tabular}{|l|c|c|}
\hline \multicolumn{1}{|c|}{ Category } & Rank & Log Determinant \\
\hline Member & 47 & 22.762 \\
\hline Non-member & 47 & 27.231 \\
\hline Pooled within-groups & 47 & 15.554 \\
\hline \multicolumn{2}{|c|}{ The ranks and natural logarithms of determinants printed are those of the group covariance matrices } \\
\hline
\end{tabular}

Source: Discriminant analysis results

Table 6 shows the Eigen Values and the Canonical Correlation. An Eigen Value of more than one is considered to reveal a good model. The computed Eigen Value is 3.901, showing that the Discriminant Model is a good one.

Table 6. Summary of Group Discriminant Functions: Eigen Values

\begin{tabular}{|l|l|l|l|l|}
\hline Function & $\begin{array}{l}\text { Eigen } \\
\text { Value }\end{array}$ & $\%$ of Variance & Cumulative \% & Canonical Correlation \\
\hline 1 & 3.901 & 100.0 & 100.0 & 0.892 \\
\hline \multicolumn{2}{|l|}{ First 1 canonical discriminant functions were used in the analysis } \\
\hline
\end{tabular}

Source: Discriminant analysis results

The Canonical Correlation is the measure of the association between the groups in the independent variable and the discriminant function. The table shows a very high Canonical Correlation of 0.892 , signifying high association between the groups in the independent variable and the discriminant function.

Table 7. Summary of Group Discriminant Functions: Wilks' Lambda

\begin{tabular}{|l|l|l|l|l|}
\hline Test of Function(s) & Wilks' Lambda & Chi-square & df & Sig. \\
\hline 1 & 0.204 & 595.248 & 47 & 0.000 \\
\hline
\end{tabular}

Source: Discriminant analysis results

Wilk's Lambda measures the significance of the Discriminant function. The Table 4 shows the Wilk's Lambda to be a low 0.204. The Chi-Square Value is 595.248 and its Significance level is 0.000 . The results reveal that the prediction model is statistically significant, and that the independent variables are able to predict the outcome at a statistically significant level.

Table 8. Discriminant Analysis: Classification Results

\begin{tabular}{|c|c|c|c|c|c|}
\hline & & \multirow{2}{*}{ Category } & \multicolumn{2}{|c|}{ Predicted Group Membership } & \multirow{2}{*}{ Total } \\
\hline & & & member & non-member & \\
\hline \multirow{4}{*}{ Original } & \multirow{2}{*}{ Count } & member & 298 & 2 & 300 \\
\hline & & non-member & 8 & 92 & 100 \\
\hline & \multirow{2}{*}{$\%$} & member & 99.3 & 0.7 & 100.0 \\
\hline & & non-member & 8.0 & 92.0 & 100.0 \\
\hline \multirow{4}{*}{ Cross-validated } & \multirow{2}{*}{ Count } & member & 297 & 3 & 300 \\
\hline & & non-member & 21 & 79 & 100 \\
\hline & \multirow{2}{*}{$\%$} & member & 99.0 & 1.0 & 100.0 \\
\hline & & non-member & 21.0 & 79.0 & 100.0 \\
\hline \multicolumn{6}{|c|}{\begin{tabular}{|l} 
a. $\quad 97.5 \%$ of original grouped cases correctly classified. \\
\end{tabular}} \\
\hline \multicolumn{6}{|c|}{$\begin{array}{l}\text { b. Cross validation is done only for those cases in the analysis. In cross validation, each case is classified by the functions } \\
\text { derived from all cases other than that case. }\end{array}$} \\
\hline
\end{tabular}

Source: Discriminant analysis results 


\section{ENTREPRENEURSHIP AND SUSTAINABILITY ISSUES}

ISSN 2345-0282 (online) http://jssidoi.org/jesi/

2020 Volume 7 Number 4 (June)

http://doi.org/10.9770/jesi.2020.7.4(56)

Table 8 presents the Classification results. It gives information on how accurately the predictor model was able to predict the actual results. In the Original grouped cases, the model correctly classified 99.3 per cent of members, and $92 \%$ of non-members, thereby having a $97.5 \%$ overall correct classification.

In the Cross-Validated grouped cases, 99.0 per cent of members were correctly classified by the model, whereas 79 per cent of non-members were correctly classified. The overall correct classification in the cross-validated grouped cases was 94 per cent.

Thus, the hypothesis SHG members and non-members cannot be discriminated based on their entrepreneurial competencies stand REJECTED.

\section{Research Limitations}

The study is based on sample survey method. The finding of the sample analysis is generalized to the population. Thus all the limitations of a sample survey vis-à-vis census survey apply to the study. Though the study is done at the State-level, the data collection was limited only to three coastal districts of Kerala. However, every step had been taken to ensure representativeness of the sample, data, and analysis. Thus, the findings of the study can tolerably be generalized to the entire population. Respondents for the study consisted of coastal women-folk. The precision and reliability of the data elicited from them are bound by their skills of perception and comprehension. Owing to the importance of this fact, sufficient caution (eg. administering the interview schedule in local language with local assistance] was taken to mitigate the adverse effect.

\section{Conclusions}

The study was intended to find out the level of entrepreneurial competencies achieved by women micro entrepreneurs (both members and non-members of SHGs) in coastal Kerala. In order to investigate whether or not entrepreneurial competencies can discriminate between members and non-members of SHGs, discriminant analysis was performed. The study revealed that there exists significant difference (at 95\% Confidence level) between the levels of entrepreneurial competency of members and non-members. Results of discriminant analysis reveled that SHG member and non-member women micro entrepreneurs can be discriminated based on their entrepreneurial competencies, which implies that SHGs play a catalytic role in contributing the entrepreneurial competency development of their members, who becomes micro entrepreneurs. The findings of the current study indicate that competency matters in describing sustainability of the entrepreneurial venture. The study results may help the academia, trainers and researchers to identify new ways of teaching competency development. It will also help them to focus on innovative training programmes, that focuse on development of entrepreneurial competencies and to come out with tailor-made solutions to the problems of women owned enterprises. The study pinpoints the role Self Help Groups in developing entrepreneurial competency among women entrepreneurs. Policy makers' role is significant in promoting entrepreneurial competency development initiatives and also in creating awareness among women micro entrepreneurs about the importance of entrepreneurial competencies in taking competitive advantage over others in the field, so that they can ensure sustainable business performance. 


\section{ENTREPRENEURSHIP AND SUSTAINABILITY ISSUES}

ISSN 2345-0282 (online) http://jssidoi.org/jesi/

2020 Volume 7 Number 4 (June)

http://doi.org/10.9770/jesi.2020.7.4(56)

\section{References}

Abu-Saifan, S. (2012). Social entrepreneurship: Definition and boundaries. Technology Innovation Management Review, February, $22-27$.

Adam, E. \& Chell, E. (1993). The successful international entrepreneur: A profile. Paper presented at the Twenty third European Small Business Seminar. Belfast: Northern Ireland.

Alveraz, S. A., \& Barney, J. B. (2007). Discovery and creation: Alternative theories of entrepreneurial action. Strategic Entrepreneurship Journal, 1, 11-26. https://doi.org/10.1002/sej.4

Bacq, S. \& Janssen, F. (2011). The multiple faces of social entrepreneurship: A review of definitional issues based on geographical thematic criteria. Entrepreneurship and Regional development, 23(5-6), 373-403.

Bartlett, C.A. \& Ghoshal, S. (1998), Managing across borders: The transnational solution (2nd ed.), Boston: Harvard Business School Press.

Bird, B. (1995). Toward a theory of entrepreneurial competency. In J. A. Katz and R. H. Brockhaus, Sr (Eds.), Advances in entrepreneurship, firm emergence and growth (pp. 51-72). Greenwich, Conn: JAI Press

Boyatzis, R.E. (1982). The competent manager: A model for effective performance. London: Wiley.

Brophy, M., \& Kiely, T. (2002). Competencies: A new sector. Journal of Industrial Training, 26(2/3/4), 165-176.

Brouard, F., \& Larivet, S., (2010). Essay of clarifications and definitions of the related concepts of social enterprise, social entrepreneur and social entrepreneurship. In Fayolle A., and Matlay H. (Eds.), Handbook of research on social entrepreneurship, Chetelham: Edward Elgar.

Busines Standard (2018). Capital Market. Available at https://www.business-standard.com/article/news-cm/women-constitute-around14of-total-entrepreneurship-in-country-118071600642_1.html

Canadian Centre for Social Entrepreneurship. (2001). Social Entrepreneurship. Discussion paper No.1. https://doi.org/10.1.1.194.4683\&rep=rep1\&type=pdf

Cannon, Carl. (2000). Charity for Profit: How the new social entrepreneurs are creating good by sharing wealth. National Journal, 16, 1898-1904.

Fornell, C., \& Larcker, D.F. (1981). Evaluating structural equation models with unobservable variables and measurement error. Journal of Marketing Research, 18(1), 39-50.

Garavan, T. \& McGuire, D. (2001). Competencies and workplace learning: Some reflections on the rhetoric and the reality. Journal of Workplace Learning, 13(4), 144-164.

Gibb, A. A. (2005). The entrepreneur as the core competence of the firm: Implications for management educators. Entrepreneurship, Innovation and Small Business Network, (2)2.

Hair, J. F. Jr., Black, W. C., Babin, B. J., \& Anderson, R. E. (2009). Multivariate data analysis, (7th ed.) Upper Saddle River, NJ: Prentice Hall.

Kerlin, J. (2006). Social enterprise in the United States and Europe: Understanding and learning from the differences. Voluntas, 17, 247263.

Kumar, Parveen. (2018). A study of Entrepreneurs in India. International Journal of Applied Science \& Technology Research Excellence. 5(5), 43-46.

Lau, T., Chan, K.F. \& Man, T.Y.Y. (2000). The entrepreneurial and managerial competencies of small business owner/managers in Hong Kong: Conceptual and methodological considerations. In Sancehez, R. \& Heene, A. (Eds.), Research in competence-based management: Advances in applied business strategy, Connecticut: JAI Press. 187-216. 


\section{ENTREPRENEURSHIP AND SUSTAINABILITY ISSUES}

ISSN 2345-0282 (online) http://jssidoi.org/jesi/

2020 Volume 7 Number 4 (June)

http://doi.org/10.9770/jesi.2020.7.4(56)

Mair, J., \& Nobao, E., (2003). Social entrepreneurship: How intentions to create a social enterprise get forward. Working Paper 521, IESE Business school University of Navarra. Retrieved from http://www.sireview.org/articles/entry/social_entrepreneurship

McClelland, D. C. (1973). Testing for competence rather than for intelligence. American Psychologist, 28, 1-14.

McGregor, J., \& Tweed, D., (2002). Profiling a new generation of female small business owners in New Zealand: Networking, mentoring and growth, Gender, Work and Organization, 9(4), 420-438.

Miller, T. L., Wesley II, C. L. \& Williams, D. E. (2012). Educating the minds of caring hearts: comparing the views of practitioners and educators on the importance of social entrepreneurship competencies. Academy of Management Learning and Education, 11(3), 349-370.

Minimol, M. C. (2017). Linkage between entrepreneurial competency and social entrepreneurship: Evidences from SMEs in Kerala. Asian Social Science,13(10), 31-42. https://doi.org/10.5539/ass.v13n10p31

Mitchelmore, S., \& Rowley, J. (2010). Entrepreneurial competencies: a literature review and development agenda. International Journal of Entrepreneurial Behavior and Research, 16(2), 92-111. http://dx.doi.org/10.1108/13552551011026995

Muzychenko, O. \& J., Saee (2004). Cross cultural professional competence in higher education. Journal of Management Systems, 16(4), 119.

Ngoasong, Michael \& Kimbu, Albert (2019). Why Hurry? The Slow Process of High Growth in Women-Owned Businesses in a Resource-Scarce Context. Journal of Small Business Management, 57(1), 5-13

Nunnally, J. C., \& Bernstein, I. H. (1994). Psychometric theory (3rd ed.). New York: McGraw-Hill.

Nyssens, M. (2006). Social enterprise at the crossroads of market, public policies and civil society. London: Routledge.

Prahalad, C. K. (2006). The innovation sandbox. Strategy+Business, Autumn, 44, 62-71. Retrieved from www.strategybusiness.com/press/freearticle/06306

Ramasamy, H. (1995). Productivity in the age of competitiveness: Focus on manufacturing in Singapore. APO Monograph Series, 16, Asian Productivity Organization.

Schouten, M.J. (2019). Undoing gender inequalities: insights from the Portuguese perspective. Insights into Regional Development, (2), 85-98. https://doi.org/10.9770/ird.2019.1.2(1)

Spencer, L. M., \& Spencer, S.M. (1993). Competence at work. Human resource quarterly, New York: Wiley, 372.

Sreemoyee, D., Mitra, A., \& Ali, M.H.(2015). A study on the impact of women Self Help Groups on the rural entrepreneurship development: A case study in selected areas of West Bengal. International Journal of Scientific and Research Publications, 5(3)

Stuart, R. \& Lindsay, P. (1997). Beyond the frame of management competencies: Towards a contextually embedded framework of managerial competence in organizations. Journal of European Industrial Training. 21(1), 26-33.

Thompson, J., Alvy, G. \& Lees, A. (2002). Social entrepreneurship: A new look at the people and the potential. Management Design, $38(5), 328-338$.

Thyagaraj (2017). Women Entrepreneurship Development Practices in India: A Review. Global Journal for Research Analysis, 6(9), 173175.

Thandabhani, M. (2020). Strategic communication for women entrepreneurs: a case study of India. Insights into Regional Development 2(1): 480-497. https://doi.org/10.9770/IRD.2020.2.1(7)

UNIDO (2002). Strengthening organizational core values and managerial capabilities. Human Resource Management Branch, UNIDO. http://www.unido.org/fileadmin/media/documents/pdf/Employment/UNIDOCompetency

Veronika, Biksea, Baiba, Rivzab, \& Inga, Riemere (2015). The Social Entrepreneur as a promoter of social advancement. Procedia - Social and Behavioral Sciences, 185, 469-478. 


\section{ENTREPRENEURSHIP AND SUSTAINABILITY ISSUES}

ISSN 2345-0282 (online) http://jssidoi.org/jesi/

2020 Volume 7 Number 4 (June)

http://doi.org/10.9770/jesi.2020.7.4(56)

Wiklund, J. (1999). The sustainability of the entrepreneurial orientation: Performance relationship. Entrepreneurship Theory and Practice (Fall), 37-48.

Wonphuka, K., Teeradej, C. A., Supavan, P., Piyawat, B.N. (2017). Social entrepreneur competencies of social activists involved with children and youth: A case study of Nan Province, Thailand. Kasetsart Journal of Social Sciences, 38, 143-149.

Yadav, V., Unni, J. (2016). Women entrepreneurship: research review and future directions. Journal of Global Entrepreneurship Research. 6(12) https://doi.org/10.1186/s40497-016-0055-x

Zahra, S. A., Rawhouser, H. N, Bhawe, N., Neubaum, D. O., \& Hayton, J. C. (2008). Globalisation of social entrepreneurship opportunities. Strategic Entrepreneurship Journal, 2(2), 117-131.

Zampetakis, L. A. (2008). The role of creativity and pro-activity on perceived entrepreneurial desirability. Thinking Skills and Creativity, $3(2), 154-162$.

\section{Acknowledgements}

This research was supported by the Indian Council of Social Science Research (ICSSR), New Delhi, through its sponsored research programme.

Minimol M C is the Associate Professor of Finance at Rajagiri College of Social Sciences, Kochi, Kerala, India. Her research papers are published in various scopus and ABDC indexed journals of repute. Research interests: entrepreneurship and regional development, sustainability, sustainable financial performance.

ORCID ID: orcid.org/0000-0002-6295-3881

Copyright (C) 2020 by author(s) and VsI Entrepreneurship and Sustainability Center

This work is licensed under the Creative Commons Attribution International License (CC BY).

http://creativecommons.org/licenses/by/4.0/

CC) (i) Open Access 